\title{
Is There a Change? Distance Education Studies in COVID-19 Pandemic
}

\author{
Gürhan Durak ${ }^{1}$ and Serkan Çankaya ${ }^{2}$ \\ ${ }^{1}$ Balıkesir University \\ Balıkesir, Turkey \\ Email: gurhandurak [AT] balikesir.edu.tr \\ 2 İzmir Demokrasi University \\ İzmir, Turkey \\ Email: serkan.cankaya [AT] idu.edu.tr
}

\begin{abstract}
With the Coronavirus epidemic in China at the end of 2019 and in the rest of the World in the first quarter of 2020, all educational institutions started to give distance education partially or completely. Institutions were not ready for such a process, and they failed to the necessary preparations. That's why these applications are called emergency distance education. As a result, for the evaluation of distance education prac tices during the pandemic period, a number of studies have been published and continue to be conducted. Evaluation of these publications with content analysis will be very importantin analyzing this period in the future. In this respect, the purpose of this st udy was to perform the content analysis of the articles related to distance education practices in the pandemic period. As a result of the search done using the Scopus database, a total of 180 articles were examined within the scope of the present study. The articles were examined in terms of country, number of times of citation, keywords, participants, data collection tools, variables / research interests, research designs and methods. Consequently, it was seen that the publications were mostlydone in the USA; Opinion, Reflection and Review studies were conducted and cited most; that mostly the keywords oflearning, online, education and covid-19 were used; that the participants were mostly undergraduate students; that the most frequent data collection tool was questionnaire; and that the most frequent dependent variables were engagement, readiness, perception and self-efficacy. The findings obtained were disc us sed in line with the related literature, and various suggestions were put forward.
\end{abstract}

Keywords - covid-19, distance learning, research trends, systematic review, content analysis

\section{INTRODUCTION}

Although the history of dis tanceeducation is very old, it would notbe wrong to say that it is now in its most po pular period in its history. It was impos sible to predict that the virus, which emerged at the beginning of 2020, would affect our lives so much. With the spread of the virus, this change has undoubtedly begun to influ ence the field of education as well [1]-[3]. Countries limited theireducational activities within the scope of the quarantine measures an d then decided to make use of distance education. Some countries adapted themselves to this change more quickly and at once, while others first limited their traditional education and u sed dis tance education as a support and then completely s witched to distance education.

Many studies have been carried out to reveal the effects of the pandemic process on education besides its effects on our lives. While the previous studies on dis tance education focused on certain areas, distance education studies started to be carried out in almost all fields of science especially during the pandemic period. Since the field of distanceeduc ation is itself a versatile field, it could be associated with all scientific fields. It could be stated that the field of distance education, which has various dimensions such as learner, teacher, technology, support services, method and evaluation, is also quite extensive and comprehensive. The importance of distance education is increasing day by day [4], es pe cially during this pandemic process, because alleducation and training activities are being given via dis tance education and because the possibility of using such applications in the future is increasing. Figure 1 presents the studies in the W OS database conducted in related literature in the last 10 years. 


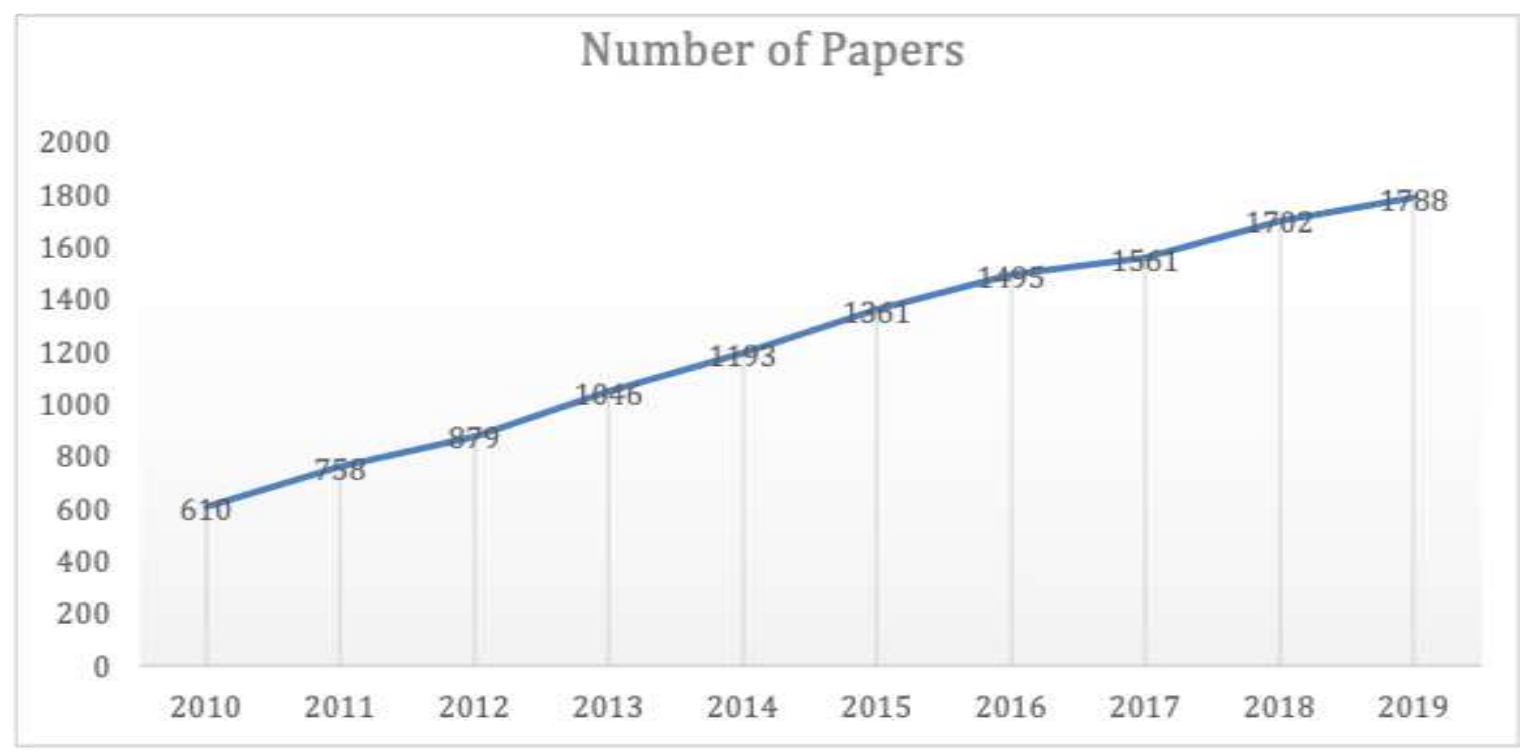

Figure 1. Number of Papers in Web of Science Database

As can be seen in Figure 1, it could be stated that distance education has become an increasingly important concept in related literature. It is known that many studies have been carried out in this field with the spread of the Internet especially after the 2000s. The year 2020 has been a year in which education and training processes are being carried out via distanceeducation all over the world in the pandemic process. Researchers are study ing on dis tance education systems, course designs and all sub-dimensions of dis tance education in this pandemic process. Thesestudies can also be evaluated as a feedback mechanis mby institutions and system designers.

The most important aspect of this study is to reveal the analyses of the studies conducted on distance education during the pandemic process and to draw related conclusions. Accordingly, in the study, conclusions will be drawn. In addition, it is important to make comparisons of the studies conducted in the pandemic period in various respects ranging from methodology to participants' preferences and fromthe research topics of the studies to the fin dings obtain ed in these studies. In this respect, the purpose of this study is to examine the studies in the field of distance education / online learning in the scopus database in terms of certain variables during the pandemic period.

In accordance with this aim the following topics were considered:

- Distribution of thearticles by journals

- Major contributor countries

- Keywords,

- Most cited articles

- Research areas,

- Employed research designs/models,

- Data collection tools

- Dependent variables,

- Participants (with sample size),

\section{RELATED LITERATURE}

In literature, there are many analysis studies in the field of "distance education/ le arning ". While some of the se studies are directly related to the field of distance education, some of them are studies conducted on various dimen sions of distance education. In this study, because the distance education studies conducted in the Covid-19 pandemic period were analyzed in general terms, the focus was on general analysis studies conducted in the field of distance education in related literature. Table 1 includes some of the analysis studies appropriate to this definition in the literature. 
Table 1. Summary of the Literature Related to Distance Education

\begin{tabular}{|c|c|c|c|}
\hline Author(s) & Highlights of Research Findings & Years & $\begin{array}{l}\text { Number of } \\
\text { papers }\end{array}$ \\
\hline $\begin{array}{l}\text { Koble \& Brunker, } 1997 \\
\text { [5] }\end{array}$ & Mostly preferred methods: quantitative methods & $\begin{array}{l}1989- \\
1997\end{array}$ & 129 articles \\
\hline Mishra, 1997 [6] & $\begin{array}{l}\text { Mos tly preferred methods: descriptive methods. } \\
\text { Mos tly preferred data collection tools: questionnaire and scales. } \\
\text { Top countries: UK, USA, Australia }\end{array}$ & $\begin{array}{l}1991- \\
1996\end{array}$ & 361 articles \\
\hline $\begin{array}{l}\text { Zawacki-Richter, } \\
\text { Backer \& Vogt, } 2009 \\
\text { [7] }\end{array}$ & $\begin{array}{l}\text { Mostly preferred research areas: interaction and communication. } \\
\text { Least preferred research areas: costs and advantages. Top } \\
\text { Countries: USA, Canada, UK }\end{array}$ & $\begin{array}{l}2000- \\
2008\end{array}$ & 695 articles \\
\hline $\begin{array}{l}\text { Davies, Howell \& } \\
\text { Petrie, } 2010 \text { [8] }\end{array}$ & $\begin{array}{l}\text { Mos tly preferred methods: Survey and case study. Mostly preferred } \\
\text { data collection tools: Questionnaire. }\end{array}$ & $\begin{array}{l}1998- \\
2007\end{array}$ & $\begin{array}{l}308 \text { master } \\
\text { thesis and } \\
\text { dis sertations }\end{array}$ \\
\hline Horzum et al. 2013 [9] & $\begin{array}{l}\text { Mostly preferred methods: quantitative methods. Mostly used } \\
\text { dependent variables: achievement, satisfaction and attitude. } \\
\text { Mostly preferred data collection tools: interview, document } \\
\text { analys is and scale. }\end{array}$ & $\begin{array}{l}2005- \\
2011\end{array}$ & 35 articles \\
\hline $\begin{array}{l}\text { Bozkurt et al., } 2015 \text { a } \\
{[10]}\end{array}$ & $\begin{array}{l}\text { Mostly preferred res earch areas: instructional design. Mostly } \\
\text { preferred methods: quantitative methods. Mostly preferred data } \\
\text { collection tools: questionnaire, interview and scale. Mostly } \\
\text { preferred participant type: undergraduate students. }\end{array}$ & $\begin{array}{l}1986- \\
2014\end{array}$ & $\begin{array}{c}61 \\
\text { dis sertations }\end{array}$ \\
\hline $\begin{array}{l}\text { Bozkurt et al. } 2015 b \\
{[11]}\end{array}$ & $\begin{array}{l}\text { Mostly preferred methods: mixed methods with exploratory } \\
\text { sequential and explanatory sequential designs. Mostly preferred } \\
\text { data collection tools: questionnaire, interview and document } \\
\text { analysis. Mostly preferred participant type: undergraduate } \\
\text { students. }\end{array}$ & $\begin{array}{l}2009- \\
2013\end{array}$ & 861 articles \\
\hline Duraket al., 2017 [12] & $\begin{array}{l}\text { Mostly preferred research areas: educational technology. Mostly } \\
\text { preferred methods: quantitative methods. Mostly preferred data } \\
\text { collection tools: questionnaire, interview and scale. Mostly } \\
\text { preferred participant type: undergraduate students. Mostly prefered } \\
\text { dependent variables: academic performance, attitude. }\end{array}$ & $\begin{array}{l}1986- \\
2015\end{array}$ & $\begin{array}{l}285 \text { Master's } \\
\text { theses }\end{array}$ \\
\hline Bozkurt et al., 2017 [13] & $\begin{array}{l}\text { Mostly preferred research areas: theories and models. Mostly } \\
\text { preferred methods: conceptual/descriptive, quantitative. }\end{array}$ & $\begin{array}{l}2008- \\
2015\end{array}$ & 362 articles \\
\hline $\begin{array}{l}\text { MusaudAsdaque et al., } \\
2018[14]\end{array}$ & $\begin{array}{l}\text { Mostly preferred research areas: ins tructional design. Mostly } \\
\text { preferred data collection tools: questionnaire and scale. Mostly } \\
\text { preferred participant type: teachers. Mostly preferred dependent } \\
\text { variables: effectiveness. }\end{array}$ & $\begin{array}{l}2001- \\
2014\end{array}$ & $\begin{array}{c}32 \\
\text { dis sertations }\end{array}$ \\
\hline $\begin{array}{l}\text { Kilıç Çakmak et.al., } \\
2016[15]\end{array}$ & $\begin{array}{l}\text { Mostly preferred research areas: ins tructional design and } \\
\text { educational technology. Mostly preferred methods: quantitative. } \\
\text { Mos tly preferred datacollection tools: questionnaire, log data. }\end{array}$ & $\begin{array}{l}2000- \\
2016\end{array}$ & 154 articles \\
\hline
\end{tabular}

Table 1 shows whomthe studies were conducted by, the prominent findings obtained in the studies (Highlights of Research Findings). in which years the studies were conducted, and what type of and how many studies were examin ed. The studies have been given in a chronological order. Apartfromthese studies, two more s y stematic review studies related to distance education were reached. In the first one, Durak and Çankaya [16] conducted a s ystematic content analys is on "Seamles s Learning" in literature. It was the first systematic review study on this concept, which is quite new in literature, and it covered a total of 58 articles. As the research methods in these studies, conceptual/descriptive methods were prominent. Moreover, as the participants, K-12 students were preferred more, and interview and academic achievement tests were the most common data collection tools. In the studies examined, the mo st popular dependent variables included academic performance and perception. 
In another study, Durak \& Çankaya [17] carried out a sys tematic study on the concept of "Learning Space". The res earchers examined a total of 95 papers for the purpose of determining the res earch methods and models, concept lis $t$, most cited papers, top journal list, data collection tools, participants and dependent variables. The study is thought to be important because no content analy sis was run on the concept of learning spaces. In these studies, the research meth ods mostly included conceptual/descriptive methods and qualitative methods; the participants were mos tly underg radu ate students; and interview and questionnaire were among the most common data collection tools. Finally, in these s tudie s, the most popular dependent variables included perception and academic performance.

\section{METHODOLOGY}

In this study, a systematic content analysis was conducted on articles found in the database of Scopus regarding the concept of "distance education / online learning". Contentanalysis is a technique which helps researchers to draw meaningful inferences by analyzing the written of vis ual written documents [18]. This type of research is thought to be effective in acting as a guide for future studies by summarizing the certain aspects of related studies in literat u re [19], [20], and in this respect, content analy sis is preferred by researchers [21].

The following criteria were taken into account while reviewing the related literature for the articles: being writte $n$ in English, being publis hed in a peer-reviewed journal and being published in the year of 2020. In order to reach the related articles, Scopus database was searched. For peer-reviewed literature, Scopus is the largest dat abas e of peer-re viewed literature [22], and scientific journals, books and conference proceedings are lis ted in Scopus [23]. A systematic search in the SCOPUS database was done by using the following search keywords: "Covid-19" AND "dis tance education" OR “online learning” OR “dis tance learning”OR “online education”. In addition, the search year was limited to 2020 to reach only the articles publis hed in the pandemic period.

As a cons equence of this search, a total of 265 articles were reached. Among all these articles, 207 of them were fulltext, and 58 articles were not included in this study because they were not reached as full-text articles, and 27 articles were excluded because they were not directly related to the topic. As a result, a total of 180 artic les were examined in relation to the key words. The overall res earch flow is presented in Figure 2.

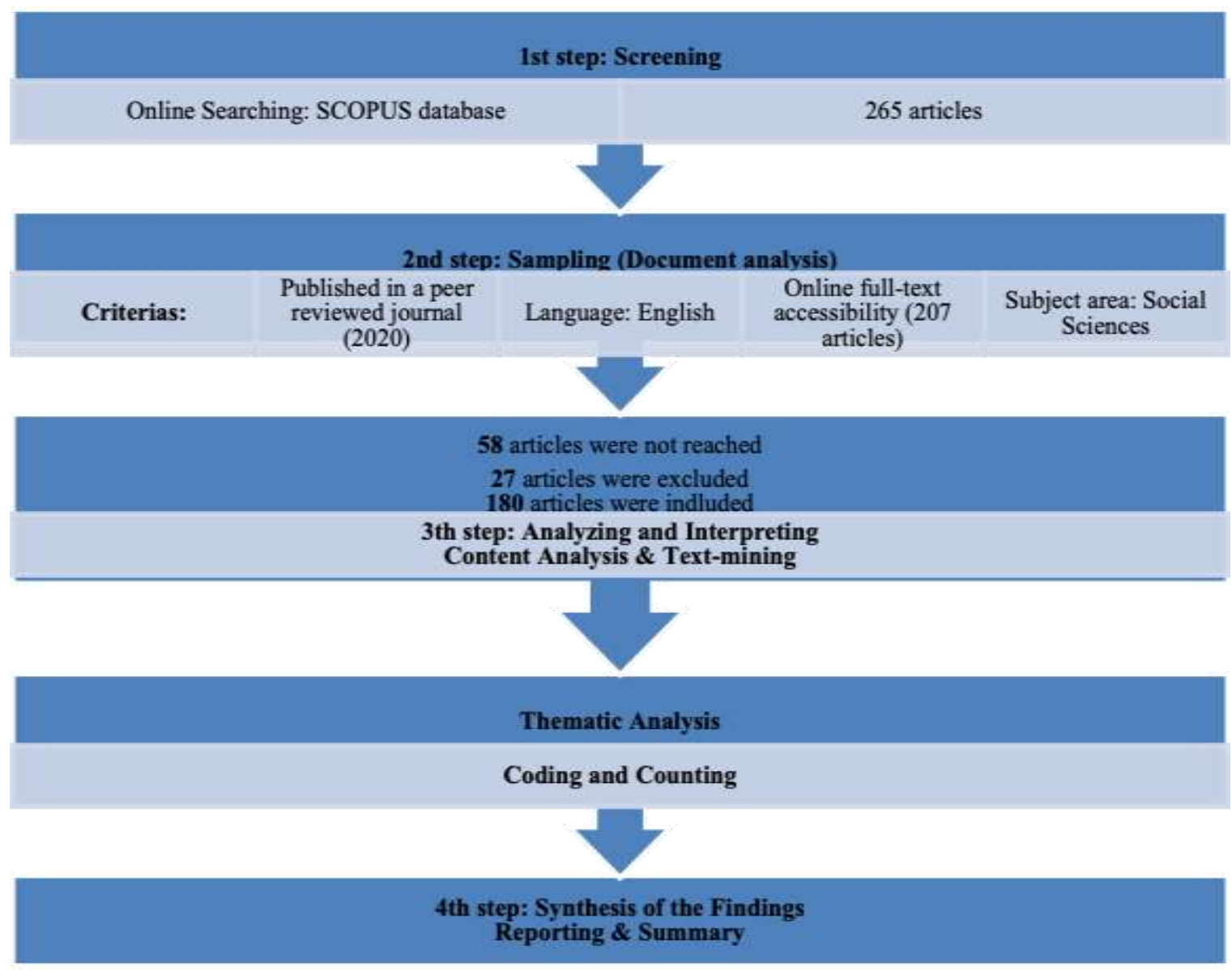

Figure 1. The Overall Reres earch Flow

In this study, in order to find answers to the res earch questions, content analysis was applied to a total of 180 full-te xt articles, and the related articles were examined considering certain variables. In the study, descrip tive statistic s were 
performed with percentages and frequencies regarding the certain as pects of the articles. Following this, these $s$ tat is tic $s$ were interpreted and comparis ons were made with the results of other sy stematic review studies in the same field.

\subsection{Reliability}

For the purpose of ensuring the reliability of the articles to be included in the review, a total of 30 articles were randomly selected fromall the articles and examined by the two researchers in accordance with the inclusion/ exclusion criteria, and the dis agreements were resolved by discussing them. Moreover, these 30 randomly selected articles were coded by two encoders considering the evaluation form to ensure intercoder reliability. For the in tercoder reliability, Cohen's Kappa coefficient was u sed and calculated as 0.72 in the first step. Following this, the two encoders discussed and agreed on the differences, and in the second calculation, Cohen's Kappa was found to be 0.92. A value of 0.75 and higher indicates an excellent reliability between encoders [24].

\section{FINDINGS AND DISCUSSIONS}

This section presents theresults of the analysis with descriptive statistics about the res earch participants, data collection tools, methods and model/designs, dependents variables, and key words in dis tance education/ online le arn in $\mathrm{g}$ area. In Figure 3, the journals where the articles were published were examined.

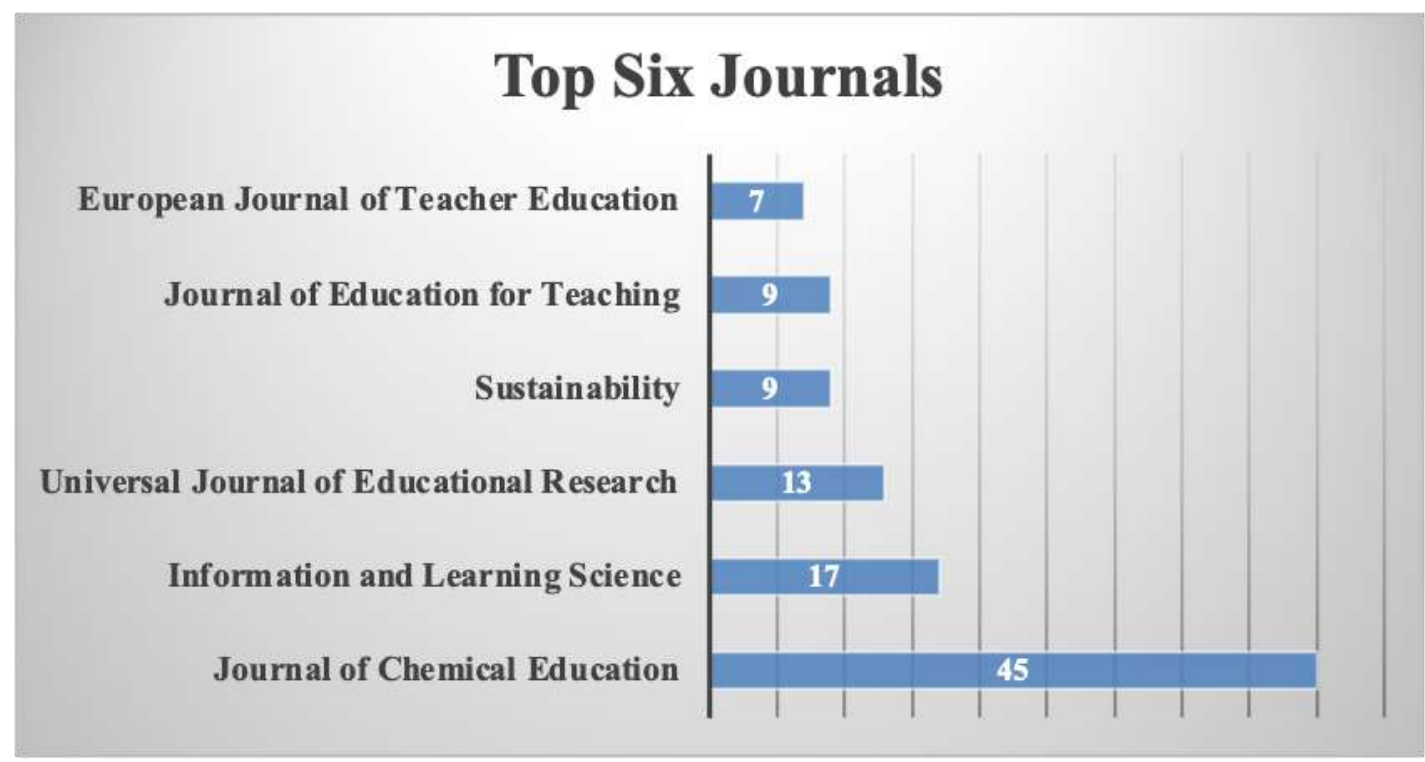

Figure 2. Journals the Articles were Published

Accordingly, the first three journals in the top-six list, where the most of the articles were published, are Journal of Chemical Education, Information and Learning Science and Universal Journal of Educational Research. It could be stated that es pecially the Journal of ChemicalEducation was not expected to have made so many publications in the field of distance education. When these publications were examined according to the methods, it was seen that the Journ al of Chemical Education made more publications of reflection papers or opinion papers and fewer publications for re $\mathrm{se}$ arch articles. It is relatively easier to produce articles in the type of reflection paperoropinion papercompared to research articles. Therefore, it could be stated that it is pos sible to have more numbers in the former type. It could be thought that lack of a data collection process in reflection papers or opinion papers leads to the production of such publications in a shorter time. However, it is known that many journals in the field prefer publications of the research article type to s u ch publications. Figure 4 shows the dis tribution of the countries where the studies were conducted. 


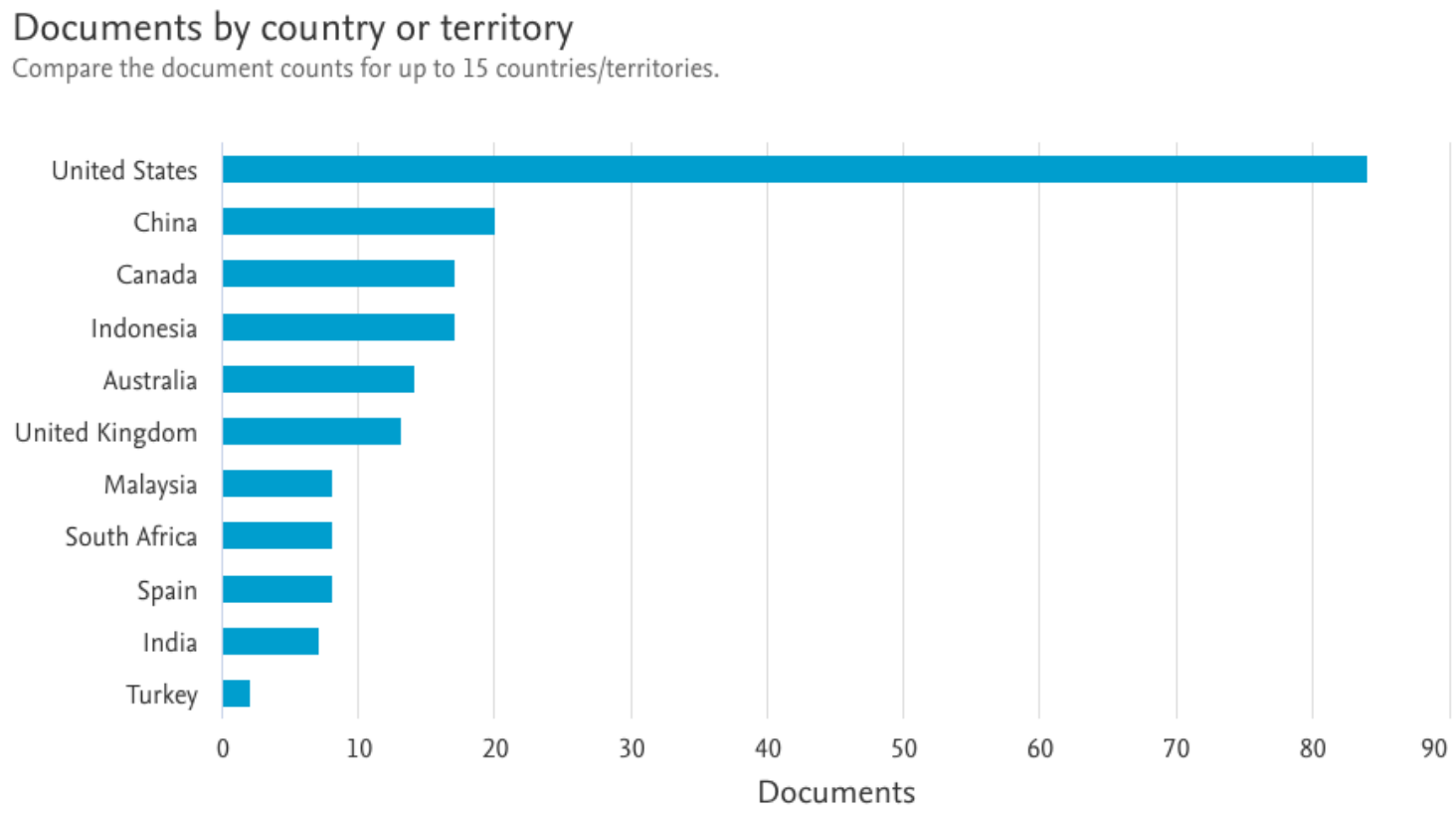

Figure 3. Countries Where the Articles were W ritten

When Figure 4 is examined, it is seen that USA is clearly ahead in the ranking of countries where the studie s were conducted. USA is followed by China, and Canadaand Indonesia are fairly close to thesecountries. It is s een that the first three countries in this list also appear as the leading countries in some of the review studies reported in literature [6], [7].

\subsection{Most Cited Studies}

The 10 most cited articles were listed within the scope of the study, and the data in Table 1 were obtained. 
Table 2. List of Articles with the Highest Number of Citations

\begin{tabular}{|c|c|c|c|c|c|}
\hline Publication Name & Authors & Journal & $\begin{array}{c}\text { Cited } \\
\text { by }\end{array}$ & $\begin{array}{l}\text { Research } \\
\text { Methods } \\
\end{array}$ & Main Focus of The Study \\
\hline $\begin{array}{l}\text { Impact of COVID- } 19 \text { on dental education in } \\
\text { the United States }\end{array}$ & Iyer et al. & $\begin{array}{l}\text { Journal of Dental } \\
\text { Education }\end{array}$ & 35 & $\begin{array}{l}\text { Theoretical/ } \\
\text { Descriptive }\end{array}$ & $\begin{array}{l}\text { This article discusses the challenges that we face currently and offers some simple } \\
\text { strategies to bridge the gaps in dental education to overcome this emergency. }\end{array}$ \\
\hline $\begin{array}{l}\text { Adaptations to a face-to-face initial teacher } \\
\text { education course 'forced' online due to the } \\
\text { COVID-19 pandemic }\end{array}$ & Moorhouse & $\begin{array}{l}\text { Journal of } \\
\text { Education for } \\
\text { Teaching }\end{array}$ & 23 & $\begin{array}{l}\text { Theoretical/ } \\
\text { Descriptive }\end{array}$ & $\begin{array}{l}\text { This report details the adaptations and challenges one tut or made to the course in } \\
\text { primary English language education. }\end{array}$ \\
\hline $\begin{array}{l}\text { Blended learning via distance in pre- } \\
\text { registration nursing education: A scoping } \\
\text { review }\end{array}$ & Jowsey et al. & $\begin{array}{l}\text { Nurse Education in } \\
\text { Practice }\end{array}$ & 12 & $\begin{array}{l}\text { Theoretical/ } \\
\text { Descriptive }\end{array}$ & $\begin{array}{l}\text { This article reports the findings of a systematic literat ure review and identifies } \\
\text { comprehensive evidence of the efficacy of blended learning for pre-registration } \\
\text { nursing students who learn across distances and/or via satellite campuses. }\end{array}$ \\
\hline $\begin{array}{l}\text { COVID-19 and digital disruption in UK } \\
\text { universities: afflictions and affordances of } \\
\text { emergency online migration }\end{array}$ & Watermeyer et al. & Higher Education & 9 & $\begin{array}{l}\text { Mixed/ } \\
\text { Triangulatio } \\
\mathrm{n}\end{array}$ & $\begin{array}{l}\text { This article reports the findings from a survey of academics working in } \\
\text { universities in the United Kingdom and representing all the major disciplines and } \\
\text { career hierarchy. }\end{array}$ \\
\hline $\begin{array}{l}\text { Impact of COVID- } 19 \text { pandemic on } \\
\text { information management research and } \\
\text { practice: Transforming education, work and } \\
\text { life }\end{array}$ & Dwivewdi et al. & $\begin{array}{l}\text { International } \\
\text { Journal of } \\
\text { Information } \\
\text { Management }\end{array}$ & 8 & Quantitave & $\begin{array}{l}\text { This study offers a collective insight to many of the key issues and underlying } \\
\text { complexities affecting organizations and society from COVID-19, through an } \\
\text { information systems and technological perspective. }\end{array}$ \\
\hline $\begin{array}{l}\text { U.S. faculty and administrators' experiences } \\
\text { and approaches in the early weeks of the } \\
\text { COVID-19 pandemic }\end{array}$ & Johnson et al. & $\begin{array}{l}\text { Online Learning } \\
\text { Journal }\end{array}$ & 8 & Qualitative & $\begin{array}{l}\text { This study reports the findings of a survey investigating the rapid transition to } \\
\text { emergency remote teaching in the early weeks of the pandemic at public and } \\
\text { private post- secondary institutions in the United States. }\end{array}$ \\
\hline $\begin{array}{l}\text { Anxiety and coping strategies among } \\
\text { nursing students during the covid-19 } \\
\text { pandemic }\end{array}$ & Savitsky et al. & $\begin{array}{l}\text { Nurse Education in } \\
\text { Practice }\end{array}$ & 7 & Quantitave & $\begin{array}{l}\text { This study assesses levels of anxiety and ways of coping among nursing students } \\
\text { in the Ashkelon Academic College, Southern District, Israel. }\end{array}$ \\
\hline $\begin{array}{l}\text { Academia in the Time of COVID-19: } \\
\text { Towards an Ethics of Care }\end{array}$ & Corbera et al. & $\begin{array}{l}\text { Planning Theory } \\
\text { and Practice }\end{array}$ & 6 & $\begin{array}{l}\text { Theoretical/ } \\
\text { Descriptive }\end{array}$ & $\begin{array}{l}\text { This article discusses how the COVID- } 19 \text { crisis is affecting our profession and } \\
\text { how it may change it in the future. }\end{array}$ \\
\hline $\begin{array}{l}\text { Secondary school mathematics teachers' } \\
\text { views on e-learning implementation barriers } \\
\text { during the COVID-19 pandemic: The case } \\
\text { of Indonesia }\end{array}$ & Mailizar et al. & $\begin{array}{l}\text { Eurasia Journal of } \\
\text { Mathematics, } \\
\text { Science and } \\
\text { Technology } \\
\text { Education }\end{array}$ & 6 & Quantitative & $\begin{array}{l}\text { This article investigates e-learning barriers experienced by Indonesian secondary } \\
\text { mathematics teachers amid the COVID-19 pandemic. }\end{array}$ \\
\hline $\begin{array}{l}\text { The perceptions of primary school teachers } \\
\text { of online learning during the covid-19 } \\
\text { pandemic period: A case study in Indonesia }\end{array}$ & Rasmitadila et al. & $\begin{array}{l}\text { Journal of Ethnic } \\
\text { and Cultural } \\
\text { Studies }\end{array}$ & 4 & $\begin{array}{l}\text { Mixed / } \\
\text { Triangulatio } \\
\mathrm{n}\end{array}$ & $\begin{array}{l}\text { This study explores the perceptions of primary school teachers of online learning } \\
\text { in a program developed in Indonesia called School from Home during the } \\
\text { COVID-19 Pandemic. }\end{array}$ \\
\hline
\end{tabular}


When Table 2 is examined, it is seen that nearly half of the most cited articles were conducted with the Theoretical/Descriptive methods. It was seen that the most frequently cited article was opinion paper, which was followed by reflection paper and then by systematic review. Especially in this pandemic process, many new application $\mathrm{s}$ were encountered in the field of education. Many people gave up their habits and tried new things. Due to this situation, people needed to reflect and interpret this experience. Therefore, an increase in the number of such articles will be an expected result during this period. Likewise, citation of such articles increases accordingly.

It was seen that the article cited in the third place was a systematic literature review study. Depending on this, the res earchers could be said to make more use of the review studies which summarized the studies in related literature. Researchers willing to conduct studies on the related research topic will be able to save time by getting in formed more about the related literature with the help of such review studies [16].

\subsection{Keyword Analysis}

Figure 6 pres ents the major keyword s covered in the reviewed articles.

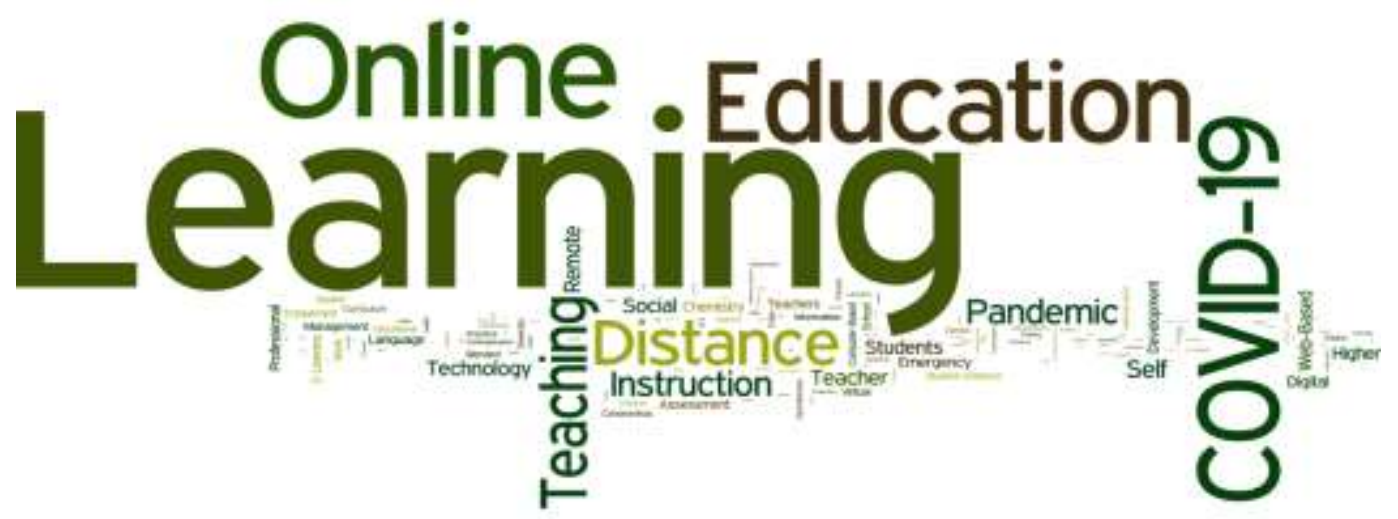

Figure 4. Major Keywords Covered

Figure 6 presents the keywords regarding the number uses in the studies. As a result, it was seen that concepts such as "learning", "online", "education" and "Covid-19" were prominent. It could be stated that the concepts in the graph with large fonts have been used extensively in related studies. It is known that the concepts of "learning", "online" and "education" are among the keywords frequently used in studies conducted in distanceeducation. The concept of Covid 19 was used in all the studies because it was among the criteria of the studies examined.

\subsection{Participants}

Table 2 presents the frequencies and percentages of the participants which were preferred in the reviewed articles.

Table 3.Participants

\begin{tabular}{l|c|c|c}
\hline Participants & Frequency & Percentage & Sample Size \\
\hline Undergraduate students & 47 & 49 & $9-7205$ \\
K-12 Teachers & 17 & 18 & $1-1174$ \\
Academicians & 11 & 11 & $4-1148$ \\
K-12 Students & 9 & 9 & $15-354$ \\
Graduate Student & 4 & 4 & $4-35$ \\
Experts & 2 & 2 & $4-12$ \\
Adult & 2 & 2 & $123-186$ \\
Administrator & 2 & 2 & $3-7$ \\
Parent & 2 & 2 & 3275 \\
\hline
\end{tabular}

\footnotetext{
*One study may use more than one participant type
} 
When the data presented in Table 3 are examined, it is seen that Undergraduate students (\%49) constituted approximately half of all the participants. Similarly some sy stematic review studies found that undergra duate s tud ent $s$ were also favored more as participants [10]-[12]. The sample sizes in the reviewed articles range from 1 to 7205 . It can be said that while the most of the sample sizes were s mall, there were also large scale studies performed in this period.

\subsection{Data Collection Tools}

Table 4 presents frequencies and percentages of the data collection tools used in the reviewed articles.

Table 4. Data Collection Tools

\begin{tabular}{lll}
\hline Data Collection Tools & Frequency & Percentage \\
\hline Questionnaire & 64 & 45 \\
Scale & 26 & 18 \\
Interview & 18 & 13 \\
Document analysis & 16 & 11 \\
Academic achievement tests & 4 & 3 \\
Focus group & 4 & 3 \\
Observation & 3 & 2 \\
Log & 3 & 2 \\
Field notes & 2 & 1 \\
GPA & 2 & 1 \\
Discussion post & 1 & 1 \\
\hline
\end{tabular}

*One study may employ more than one datacollection tools

According to Table 4, as the most popular data collection tools, questionnaire (45\%), scale (18\%), interview (13\%) and document analysis $(11 \%)$ were the most frequent ones us ed in these studies. The fact that questionnaire, s cale and interview, were the most common data collection tools is als o supported by other res earch results in related literature [6], [8]-[12], [14], [15].

\subsection{Variables/Research Interests}

The articles were examined according to the dependent variables. While there could be more than one dependent variable in a study, it was observed that no dependent variable was used in some studies. No dependent variables are used es pecially in opinion paper, reflection paper and review studies.

Table 5. Variables / Research Interests

\begin{tabular}{lll}
\hline Dependent Variables & f & $\%$ \\
\hline Engagement & 7 & 11,3 \\
Readiness & 6 & 9,7 \\
Perception & 6 & 9,7 \\
Self-efficacy & 6 & 9,7 \\
Anxiety/Stress & 5 & 8,1 \\
Academic-performance & 4 & 6,5 \\
Experience & 4 & 6,5 \\
Attitude & 4 & 6,5 \\
Skills & 3 & 4,8 \\
Effectiveness & 3 & 4,8 \\
Usefulness & 3 & 4,8 \\
Satisfaction & 3 & 3,2 \\
Interaction & 2 & 3,2 \\
Confidence & 2 & 3,2 \\
Others & 2 & 8,1 \\
\hline
\end{tabular}


According to Table 5, the most frequent dependent variable was "engagement" $(11,3 \%)$ us ed in 7 studies. This variable was followed by readiness $(9,7 \%)$ in 68 studies, "perception" $(9,7 \%)$ in 6 studies and "self-efficacy" $(9,7 \%)$ in 6 studies. It was seen that the most frequent dependent variables used in the articles were engagement, readiness, perception and self-efficacy and they constituted almost half of all the variables. However, it is seen in literature that the studies mostly focused on more general variables such as academic achievement, effectiveness, attitude and satisfaction [9], [12], [14]. The reas on for this difference in this study could be said to be the dis tance education applications in the pandemic period and the elements investigated in these applications. In this respect, it is not surprising that such elements as "Engagement", "Readiness", "Perception" and "Self-efficacy" were preferred in the studies in the pandemic period.

\subsection{Research Design and Method}

The articles were examined according to their Research Design and Methods. The results of the analysis were given in Table 5 .

Table 6. Frequencies of Methods and Models/Designs

\begin{tabular}{|c|c|c|c|c|c|c|}
\hline Method & $f$ & $\%$ & Model/Design & $f$ & \%CUM & \%TOTAL \\
\hline \multirow{4}{*}{ Quantative } & \multirow{4}{*}{45} & \multirow{4}{*}{26} & Survey & 30 & 68 & 16 \\
\hline & & & Experimental & 3 & 7 & 2 \\
\hline & & & Causal Comparative & 4 & 9 & 2 \\
\hline & & & Correlational & 7 & 16 & 4 \\
\hline \multirow{5}{*}{ Qualitative } & \multirow{5}{*}{23} & \multirow{5}{*}{13} & Case Study & 17 & 74 & 9 \\
\hline & & & Content Analysis & 3 & 13 & 2 \\
\hline & & & Descriptive & 1 & 4 & 1 \\
\hline & & & Narrative & 1 & 4 & 1 \\
\hline & & & Phenomenology & 1 & 4 & 1 \\
\hline \multirow{4}{*}{ Mixed } & \multirow{4}{*}{19} & \multirow{4}{*}{11} & Explanatory sequential & 2 & 11 & 1 \\
\hline & & & Embedded & 2 & 11 & 1 \\
\hline & & & Convergent Parallel & 16 & 77 & 9 \\
\hline & & & Exploratory Sequential & 1 & 6 & 1 \\
\hline \multirow{5}{*}{$\begin{array}{c}\text { Conceptual / } \\
\text { Descriptive } \\
\text { /Other }\end{array}$} & \multirow{5}{*}{88} & \multirow{5}{*}{49} & Literature Review & 2 & 2 & 1 \\
\hline & & & Report & 1 & 1 & 1 \\
\hline & & & Reflection Paper & 44 & 49 & 24 \\
\hline & & & Opinion paper & 38 & 42 & 21 \\
\hline & & & Systematic Review & 5 & 6 & 3 \\
\hline Practice Based & 3 & 2 & Action Research & 3 & 100 & 2 \\
\hline $\begin{array}{l}\text { Data Mining } \\
\text { and Analysis }\end{array}$ & 1 & 1 & Learning Analytics & 1 & 100 & 1 \\
\hline
\end{tabular}

The analysis reveals that res earchers mostly preferred Conceptual/Descriptive methods (49\%), while reflection paper $(n=44)$ and opinion paper $(n=38)$, were the most frequent ones used in Conceptual/Descriptive me thods. Qu an titative methods (\%26) were the second most preferred research paradigm, and among these studies, survey model $(\mathrm{n}=30)$ was the most common in these researches. Qualitative method studies scored the next highest (13\%), within which cas e studies $(n=17)$ and content analysis $(n=3)$ were the most frequent ones used in Qualitative methods. Mixed methods $(11 \%)$ and was the fourth most preferred research paradigm. Convergent parallel $(n=16)$ ) was the leading res earch model in mixed methods. In the sampled publications, only three studies preferred Practice Based method and only on e s tudy preferred Data Mining and Analysis method. The most popular res earch methods and models were different in differen $t$ review studies. In this study, the most common ones were Conceptual/Descriptive methods. On the other hand, in s o me other studies, quantitative methods were more common [5], [8]-[10], [12], [15]. Similar to the related finding obtained in the present study, in four review studies carried out by Mishra [6], Bozkurt et al. [13], Durak \& Çankaya [17] and Du rak \& Çankaya [16] Conceptual/Descriptive methods were us ed more. Therefore, in recent studies, Conceptual/Descriptive methods could be said to be have become more popular.

\section{CONCLUSION AND FUTURE RESEARCH DIRECTIONS}

In this content analysis study, 180 publications were examined to identify trends and patterns in distance education/onlinelearning area. Although there are many review articles on distance education in literature, lack of a study conducted in the pandemic period has increased theimportance of this study. Accordingly, the articles published in 2020 were determined on Scopus, which is the world's largest academic database, to examine only the articles publis hed in the pandemic period.

According to the research methods and models used in reviewed articles, it was seen that Conceptual/Descriptive methods was prominent. The Quantitative methods constituted 26\% and theQualitative methods constituted $13 \%$ of all 
the methods. In literature, while mixed method and quantitative methods are frequently used in the review studies conducted in areas such as technology and distance education, the conceptual / descrip tive methods were the most frequently used ones in this study. This situation could be explained as the preference of different rese arch topics in distance education applications in the pandemic period. In this pandemic period, the world is not experiencing an ordinary situation in any respects, and different problems and different orientations in the field of education could be said to be an expected result.

Experimental methods were not much favored in articles carried out on distance education/online learning concept. This result was not surprising, because experimental studies are those requiring more time and effort. It mig ht be quite normal that such studies have not yet appeared in this short period of time. When an evaluation was made in terms of the journals, it was seen that the journal of Chemical Education unexpectedly published the most articles in the field of distance education in the pandemic period. It was also revealed that most of the 45 articles published in this journal were of Opinion / Reflection Paper type. None of the top 6 journals in the list of journals with the highest number of publications focused on distance education. Normally, articles on distance education are expected to be publis hed in specific journals in this field. However, in the pandemic process we are in, distanceeducation has in tensely affected many scientific fields. Therefore, it is seen that studies on distance education are carried out in almost all fields.

The studies related to the concept of distanceeducation/online learning were examined with respect to the number of citations made to them. Ten most cited articles were listed. When these articles were examined, it was seen that the mo st cited 3 studies were performed with opinion/reflection/review research models found under the category of Theoretical/Descriptive methods. Thus, it could be said that the researchers cite these types of articles mostbecause they reflect the experiences and summarized the studies in related literature in a systematic way. The present study, which was also designed as systematic literature review with content analysis, is thought to be a guide for researchers who want to perform a research about distance education area. Besides, this study is important to see the changes in distance education before and after the pandemic.

As a result of the analysis of the keywords, learning, online, education and covid-19 are the mostly included keywords. These keywords are frequently used keywords in distance education, and it is not surprising that covid - 19 is among these key words with the pandemic process. In the articles undergraduate students were preferred mostly as a participant type. However, studies on k-12 teachers and k-12 students are not sufficient, and the groups most affected by this process are thought to be k-12 teachers and k-12 students. As data collection tools used in the articles, questionnaire, scale and interview were dominant. When evaluated in terms of research interest, it was seen that variables such as engagement, readiness and perception, which have not been frequently used in literature, are preferred. This situation could be said to be related to different research orient ations in the current pandemic period.

As demonstrated by the review of the related literature, there isn't any systematic content analysis conduc ted to distance education/online learning concept in covid-19 pandemic. Therefore, the present study is expected to be the firs $t$ one. Based on the findings of this research, the following suggestions were made for researchers who wants to perform studies in this concept.

It is seen in the studies that experimental research methods were almost neverpreferred. Experimental studies are very important in terms of giving first-hand data regarding the success of the education given. Researchers can inclu de more experimental studies on emergency distance education practices.

When the methods of the studies were examined, it was seen that the Mixed Method was ranked 4th in terms of popularity. Res earchers could use the mixed method more in their studies to provide data diversity.

Researchers could conduct new studies by using less popular dependent variables such as ac ademic achievement, motivation and social presence.

Researchers could carry out studies comparing the practices in different countries.

Researchers could design new content analy sis studies by using different databases and by focusing on certain aspects of distance education.

In this period, researchers have written many reflection papers to reveal the experiences of theirown ins titu tions or their countries. A detailed content analysis especially on reflection papers will be usefulin terms of seeing the whole picture.

The Data Mining and Analysis method was preferred in only one of the 180 studies. With the help of s tudies to be carried out with Data Mining and Analysis methods, valuable findings and results could be obtained from the trac es left by students on dis tance education systems. Researchers could be encouraged to do more studies using this method.

The studies were mostly carried out with undergraduate students. Undergraduate students are among those with the best self-learning skills. Therefore, these students could be said to be one of the g roup s who will benefit mos t from distance education. However, this is not the case for $\mathrm{K}-12$ students. It could be stated that especially young primary and 
kindergarten students are among the groups most affected by this process. In this respect, more studies could be conducted on this subject with K-12 students.

\section{REFERENCES}

[1] B. Şener, İ. SağlamErtem, and A. Meç, “Online teaching experiences of ELT instructors,” J. Educ. Technol. Online Learn., vol. 3, no. 3, pp. 340-362, 2020, doi: 10.31681/jetol.770418.

[2] N. E. Mbiydzenyuy andD. Silungwe, "Teaching and learning in resource-limited settings in the face of the COVID-19 pandemic," J. Educ. Technol. Online Learn., vol. 3, no. 3, pp. 211-223, 2020, doi: $10.31681 /$ jetol.732077.

[3] E. K. Agormedah, E. A. Henaku, D. M. K. Ayite, and E. A. Ansah, “Online learning in highereducation during COVID-19 pandemic : A case of ghana,” J. Educ. Technol. Online Learn., vol. 3, no. 3, pp. 183-210, 2020, doi: $10.31681 /$ jetol.726441.

[4] A. U. Kımay and B. Aydın, “A blueprint for in-service teacher training programin technology integration,” $J$. Educ. Technol. Online Learn., vol. 3, no. 3, pp. 224-244, 2020, doi: 10.31681/jetol.761650.

[5] M. A. Koble, E. L. Bunker, M. A. Koble, and E. L. Bunker, "Trends in research and practice : An examination of the American journal of distance education 1987 to 1995," Am. J. Distance Educ. ISSN, vol. 11, no. 2, pp. 19-38, 1997, doi: 10.1080/08923649709526959.

[6] S. Mishra, "A critical analy sis of periodical literature in distance education," Indian J. Open Learn., vol. 6, no. 1, pp. 40-55, 1997.

[7] O. Zawacki-richter, E. M. Bäcker, and S. Vogt, "Review of distance education research (2000 to 2008): Analysis of research areas, methods, and authorship patterns," Int. Rev. Res. Open Distrib. Learn. Rev., vol. 10, no. 6, pp. 21-50, 2009, doi:https://doi.org/10.19173/irrodl.v10i6.741.

[8] R. S. Davies, S. L. Howell, and J. A. Petrie, "A Review of Trends in Distance Education Scholarship at Research Universities in North America, 1998-2007," Int. Rev. Res. Open Distance Learn., vol. 11, no. 3, pp. 42-56, 2010.

[9] M. B. Horzum, M. Özkaya, M. Demirci, and M. Alpaslan, "Review of turkish distance education research," Inonu Univ. J. Fac. Educ., vol. 14, no. 2, pp. 79-100, 2013.

[10] A. Bozkurt, E. G. Kumtepe, A. T. Kumtepe, I. E. Aydin, M. Bozkaya, and C. H. Aydin, "Research Trends in Turkish Distance Education: A Content Analysis of Dis sertations, 1986-2014," Eur. J. Open, Distance Elearning, vol. 18, no. 2, pp. 1-21, 2015, [Online]. Available: http://www.eurodl.org/?p=current\&sp=full\&article=690.

[11] A. Bozkurt et al., "Trends in distanceeducation res earch: A content analysis of journals 2009-2013," Int. Rev. Res. Open Distrib. Learn., vol. 16, no. 1, pp.330-363, 2015, doi: 10.19173/irrodl.v16i1.1953.

[12] G. Durak et al., "Trends in distanceeducation: A content analysis of master's thesis," Turkish Online J. Educ. Technol., vol. 16, no. 1, pp. 203-218, 2017.

[13] A. Bozkurt, "Trends and patterns in mas siveopen online courses: Review and content analysis of res earch on MOOCs," Int. Rev. Res. Open Distance Learn., vol. 18, no. 5, pp. 118-147, 2017, doi: 10.19173/irrodl.v 18i5.3080.

[14] M. Mus audAsdaque, S. A. A. Rizvi, N. B. Jumani, and M. Ahmed, "Content analysis of distance education in Pakistan: A trends study of AllamaIqbal Open University Islamabad," Int. J. Distance Educ. E-Learning, vol. 3, no. 2, 2018.

[15] E. Kılıç-Çakmak et al., "2014 yılında eğitim teknolojileri alanındaki yayımlanan makalelerin incelenmesi," Eğitim Teknol. Kuram ve Uygul., vol. 6, no. 1, pp. 80-108, 2016, doi: https://doi.org/10.17943/etku.04638.

[16] G. Durak and S. Çankaya, "Seamless learning: A scoping systematic review study," J. Educ. e-Learning Res., vol. 5, no. 4, pp. 225-234, 2018, doi: 10.20448/journal.509.2018.54.225.234.

[17] G. Durak and S. Çankaya, "The current state of the art in learning spaces: A sy stematic review study," Int.J. Emerg. Technol. Learn., vol. 13, no. 11, p. 208, Nov. 2018, doi: 10.3991/ijet.v13i11.9247.

[18] S. Elo and H. Kyngas, "The qualitative content analysis process," J. Adv. Nurs., vol. 62, no. 1, pp. 107-115, 2007, doi: 10.1111/j.1365-2648.2007.04569.x.

[19] M.Petticrew and H. Roberts, Systematic reviews in the social sciences: A practical guide. Malden, MA: Blackwell Publishing Ltd, 2006.

[20] M. Schreier, Qualitative Content Analysis in Practice. Thousand Oaks, CA: Sage, 2012.

[21] V. Wils on, "Research methods: Content analy sis," Evid. Based Libr. Inf. Pract., vol. 6, no. 4, pp. 177-179, 2011, doi: $10.1177 / 0165551504044668$.

[22] E. Buyukkol Kose, G. Cetin, and E. Yunkul, "A content analysis of studies related to educational technologies in biology education,” J. Educ. Technol. Online Learn., vol. 1, no. 2, pp. 1-15, 2018, doi: 10.31681/jetol.419932.

[23] Scopus, "The world of scientific res earch is more demanding than ever before," 2018. https://www.els evier.com/solutions/scopus (accessed Jul. 18, 2018).

[24] J. R. Landis and G. G. Koch, "The measurement of observer agreement for categoricaldata," Biometrics, vol.33, no. 1, pp. 159-174, 1977. 